\title{
Modeling of Groundwater Flow and Water Use for San Luis Potosí Valley Aquifer System
}

\author{
Briseida López-Álvarez ${ }^{1}$, José Alfredo Ramos-Leal ${ }^{2}$, Noel Carbajal ${ }^{2}$, Guillermo Hernandez-García ${ }^{3}$, Janete \\ Moran-Ramírez ${ }^{4} \&$ Germán Santacruz-DeLeón ${ }^{1}$ \\ ${ }^{1}$ Water and Society Program, College of San Luis C. A. (COLSAN), Parque de Macul 155, Colinas del Parque, \\ San Luis Potosí, México \\ ${ }^{2}$ Applied Geosciences Division, Potosin Institute of Scientific and Technological Research, C.A. (IPICYT), \\ Camino a la Presa San José \# 2055, Lomas 4ª Sección, C.P. 78216, San Luís Potosí, SLP, México \\ ${ }^{3}$ Institute of Geophysics, UNAM. Circuito de la investigación Científica s/n, Ciudad Universitaria, Delegacion \\ Coyoacan, C.P. 04510, México \\ ${ }^{4}$ Graduate in Applied Geosciences, Institute for Scientific and Technological Research of San Luis Potosí, \\ IPICYT, San Luis Potosí, México \\ Correspondence: Briseida López-Álvarez, Water and Society Program, College of San Luis C. A. (COLSAN), \\ Parque de Macul 155, Colinas del Parque, San Luis Potosí, México. E-mail: blopez@colsan.edu.mx, \\ briseidalopez@yahoo.com.mx
}

Received: May 21, 2014 Accepted: June 17, 2014 Online Published: July 28, 2014

doi:10.5539/jgg.v6n3p147 URL: http://dx.doi.org/10.5539/jgg.v6n3p147

\begin{abstract}
Land use changes are currently one of the indisputable factors in the alteration of processes and cycles of the aquifer system in the San Luis Potosí Valley. Due to its importance, is considered indispensable to investigate this detrimental factor of aquifers. The aim of this research is to use a numerical flow model to analyze the impact that land use changes have had on the aquifer. A finite differences numerical model was adapted to the size and hydrological properties of the aquifer system. It consisted of a regular grid with 30 columns and 34 rows with constant spacing of 1000 meters. It has two layers; the first includes the shallow aquifer and the second, the deep aquifer. The initial hydraulic head of the model corresponds to 1986 and was verified for 1995 and 2007. The model shows the development of a drawdown cone (central valley) extending toward the industrial area (southern valley). Piezometric water levels revealed a decrease of 0.6 to 1.6 meters annually during a period from 1977 to 2007. This work demonstrates that it is the consequence of land use changes and of the incessant overall decline in groundwater reserves. Based on the flow model, population growth projections and water use change, the calculated predictions indicate that by 2021 , the total established volume of $136 \mathrm{Mm}^{3} /$ year for consume will be reached. The flow model of the San Luis Potosí Valley aquifer system shows a clear effect of the risks associated with aquifer mining.
\end{abstract}

Keywords: water use, land use change, aquifer, numerical modeling, San Luis Potosí Valley, México

\section{Introduction}

The San Luis Potosí Valley (SLPV) aquifer is located in the southwest region of the state of San Luis Potosí (SLP), with an approximate area of $1,980 \mathrm{~km}^{2}$. In terms of water management, it is part of "El Salado" Watershed Number 37 (Figure 1), and represents a zone in the SLPV with favorable hydrogeological conditions that have enabled the intensive exploitation of groundwater. The study area has a temperate climate with a warm-arid summer. The mean annual rainfall is $402.6 \mathrm{~mm}$ and the mean annual temperature in the region is $17.5^{\circ} \mathrm{C}$; mean annual potential evaporation is $2038.7 \mathrm{~mm}$.

In the early 19th century, wells supplied water to the population of SLP (Sheridan-Prieto, 2001). By 1960, 59\% of domestic water was supplied by the shallow aquifer and $41 \%$ by the deep aquifer. The supply sources have changed dramatically in recent years so that $92 \%$ of the water is obtained from the subsoil and only $8 \%$ from surface water (COTAS, 2005). The combined municipalities of SLP and Soledad de Graciano Sánchez (SGS), which embraces the urban area of the valley and they require the main demand for water, grew $30 \%$ between 1950 and 1970. Between 1970 and 1980, a staggering population increase of more than 50\% was recorded 
(Figure 2). In 2000, the amount of inhabitants in the two municipalities was equivalent to $38 \%$ of the total state population, and between 2000 and 2005 (Figure 2), the SLP metropolitan area increased 32\%, exceeding the growth of $29 \%$ between 1990 and 2000 (INEGI, 1981, 1991, 2001, 2008). This rapid urban growth strongly impacts land use, potentially affecting recharge and groundwater extraction (Noyola et al., 2009).

Flow models have been used to carry out prognostic studies and to develop management schemes for the effects of groundwater pumping (Anderson \& Wang, 1982; Sanford et al., 2004; Milzow et al., 2009; Yustres et al., 2013). Early works to develop mathematical modeling in Mexico were performed by Cruikshank (1982) and Herrera (1982 and 1989) for the Basin of Mexico. Over the last decade, 18 mathematical model applications were achieved to manage groundwater in the state of Guanajuato (Chávez et al., 2006). In SLP, similar studies were performed (SARH-CNA-UNAM, 1992; Difurt et al., 1995 and CNA, 1996-a) adapting coarse mathematical models to the SLPV aquifer system. Kohn-Ledesma (2010) developed a flow model for the SLP aquifer to propose extraction alternatives that would increase the balance of the aquifer.

Groundwater models were also applied to study the dynamics response of the ground water systems (Bredehoeft, 2002). The purpose of this article is to analyze an important portion of the groundwater flow system in the SLPV to explore the impact of water and land use changes on the deep aquifer and on the groundwater resource management. For this, a transient groundwater flow model was adapted and calibrated in the MODFLOW computer code (MacDonald \& Harbaugh, 1988) to quantify changes in the flow system. Although this kind of studies have been conducted in other parts of the world, there are not research works on the effects of water use changes on the aquifer system of SLPV and on how this factor may affect the groundwater.

\section{Economy and Population}

The SLPV aquifer is one of the most important in the state of San Luis Potosí because it supplies the capital city, which is responsible for $80 \%$ of the state's production. It also partially includes the municipalities of SLP, Soledad de Graciano Sanchez (SGS), Mexquitic de Carmona, Cerro de San Pedro and Zaragoza. The total population of these municipalities is 1, 122.502 (INEGI, 2010), which depends on groundwater to supply $95 \%$ of (COTAS, 2005) the various uses and consumes. Urban and geographic charts reveal that in the regional development in the last decades, social and economic considerations are among the most important drivers of landscape change (Turner et al., 1996).
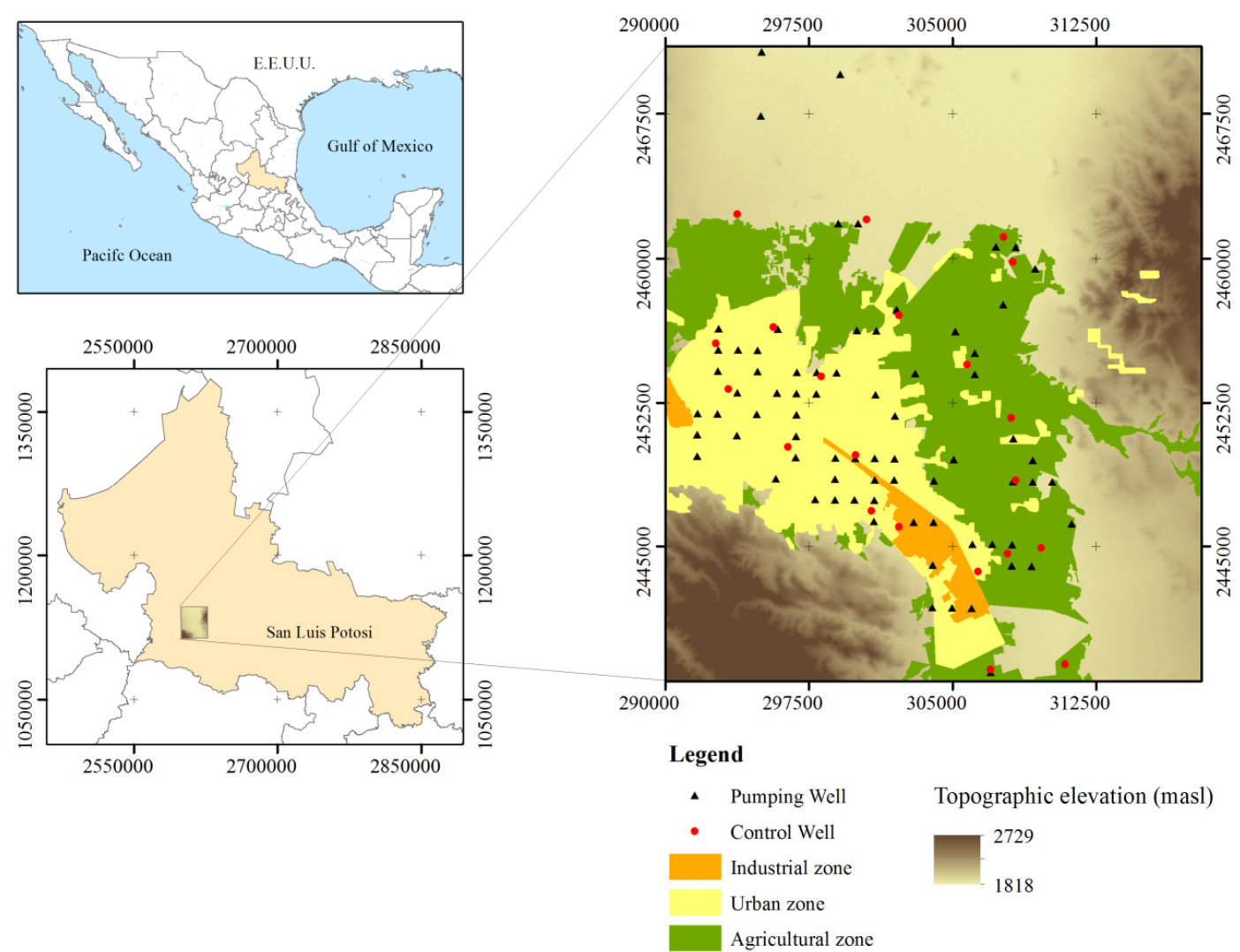

Figure 1. Location of the San Luis Potosí Valley and wells with hydraulic heads in 1995 and extractions in 1998 


\subsection{Water and Land Use}

Water and land use changes can substantially alter hydrologic ecosystem services (Kepner et al., 2012). In recent decades, land use change in the SLPV has become one of the indisputable factors in the alteration of the processes and cycles that have existed since the early years of the last century. Figure 1 shows the distribution of the three main land uses in the study area.

\subsection{Urban Land Use}

One of the first and principal factors for changes in the SLPV is the urban land use. Nowadays it remains growing and changing over time. Population growth coupled with rapid urban expansion and increasing economic and productive (industrial and agricultural) activities have put severe pressure on natural resources in the SLP Valley and on groundwater consume, in particular.

Therefore, the greatest urban demand has been concentrated in the central valley (urban zone), greatly stressing and impacting the aquifer system and causing a large drawdown cone.

Some of the conditions created by the urban area include domestic and industrial wastewater discharges which travel through open channels. These wastewaters are used in the agriculture, impacting directly the perched aquifer. In fact, it is wrong handling of wastewater, since their use occurs primarily in the agriculture with the argument that the water quality is not suitable for human consumption.

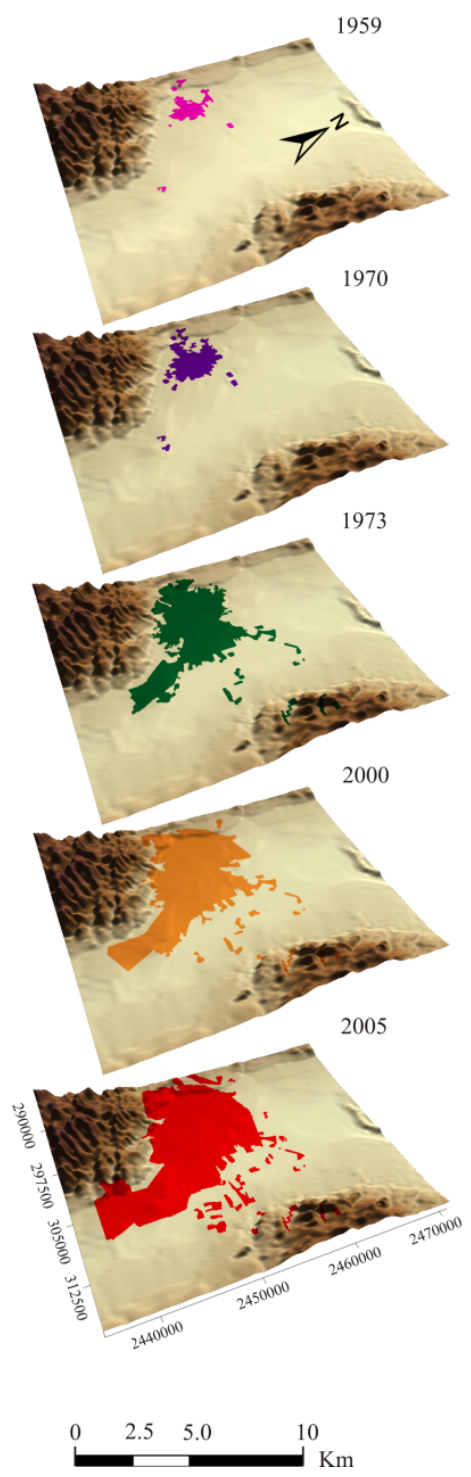

Figure 2. Growth of the urban area from 1959 to 2005, from satellite imagery (modified from Lopez-Alvarez et al., 2013) 
The accelerated urban and population growth in recent years and has led invariably to a significant change that greatly impacts the aquifer (Figure 2). The most significant change in urban land occurred between 1970 and 1993 (Noyola et al., 2009), when the area of the urbanized zone quadrupled and the suburbs in SLP experienced a 15-fold increase in size from 1959 to 2005 (Figure 2). According to Peña (2006), the distribution of the use of extracted water was $90.82 \mathrm{Mm}^{3} /$ year for domestic use and $3 \mathrm{Mm}^{3} /$ year for other uses.

\subsection{Agricultural Land Use}

Historically, agricultural development in the valley has been directed towards increasing the productivity and exploitation of natural resources while ignoring the complex interactions and implications of these processes. As a result, agriculture has represented for a long time the second largest land use and has had a high impact on the shallow aquifer. Artificial recharge induced by the use of wastewater for agricultural irrigation has resulted in hydrogeochemical anomalies in the shallow aquifer, which may result from the impact of the agricultural zone on the aquifer. The volume water for agriculture use was $8.57 \mathrm{Mm}^{3} /$ year.

\subsection{Industrial Land Use}

Although mining was the dominant industrial activity in SLP for centuries, other industries have developed in recent decades, including food, automotive, chemical, textile, paper, steel and metal mechanics. The increasing industrial activity and its corresponding displacement of the peri-urban, agriculture have intensified the demand for water, since agricultural demand for the resource is cyclical. Today, the industrial and urban changes in land use require a constant volume and permanent supply of water (SEMARNAT, 2008). The consequence of this land use change is the development of a large drawdown cone in the urban area, extending to the industrial zone. Industrial demand increase in nine years (1996-2005), from 7.6 to $13.24 \mathrm{Mm}^{3} /$ year, while in the same period agriculture decreased from 19.55 to $8.57 \mathrm{Mm}^{3} /$ year (Table 1). SEMARNAT (2008) recognized that the growing industry currently occupies spaces that were intended for agriculture, claiming $14 \%$ of the water extracted from the aquifer. The distribution of the use of extracted water was $13.24 \mathrm{Mm}^{3} /$ year for industrial use.

Table 1. Annual extractions during the period $1995-2005$, by type of use $\left(1 \times 106 \mathrm{~m}^{3} /\right.$ year $)$

\begin{tabular}{ccccccc}
\hline Year & $\begin{array}{c}\text { Human } \\
\text { use }\end{array}$ & $\begin{array}{c}\text { Agricultural } \\
\text { use }\end{array}$ & $\begin{array}{c}\text { Livestock } \\
\text { use }\end{array}$ & $\begin{array}{c}\text { Industrial } \\
\text { use }\end{array}$ & $\begin{array}{c}\text { Other } \\
\text { uses }\end{array}$ & $\begin{array}{c}\text { Annual } \\
\text { Total }\end{array}$ \\
\hline $\mathbf{1 9 9 5}$ & 66.09 & 5.72 & 0.50 & 6.80 & 1.93 & 81.04 \\
$\mathbf{1 9 9 6}$ & 67.58 & 19.55 & 0.43 & 7.60 & 1.93 & 97.09 \\
$\mathbf{1 9 9 7}$ & 69.06 & 16.97 & 0.45 & 8.41 & 1.93 & 96.82 \\
$\mathbf{1 9 9 8}$ & 70.55 & 18.92 & 0.92 & 9.21 & 1.93 & 101.53 \\
$\mathbf{1 9 9 9}$ & 72.03 & 21.93 & 1.02 & 10.02 & 1.93 & 106.93 \\
$\mathbf{2 0 0 0}$ & 73.51 & 20.15 & 1.52 & 10.82 & 1.93 & 107.94 \\
$\mathbf{2 0 0 1}$ & 77.20 & 16.59 & 1.54 & 11.63 & 1.93 & 108.88 \\
$\mathbf{2 0 0 2}$ & 78.64 & 16.32 & 1.55 & 12.44 & 1.93 & 110.87 \\
$\mathbf{2 0 0 3}$ & 85.99 & 16.98 & 1.55 & 13.24 & 1.93 & 119.69 \\
$\mathbf{2 0 0 4}$ & 89.97 & 8.57 & 1.55 & 13.24 & 1.93 & 115.26 \\
$\mathbf{2 0 0 5}$ & 90.82 & 8.57 & 1.55 & 13.24 & 1.93 & 116.10 \\
Percentage extracted by & $78.2 \%$ & $7.4 \%$ & $1.3 \%$ & $11.4 \%$ & $1.7 \%$ & \\
type of use for 2005 & & & & &
\end{tabular}

\section{Geology}

The SLP tectonic valley was filled with alluvial deposits that originated in the Sierra de San Miguelito (SSM), which resulted in a graded distribution, with preferential northeast direction. It is bounded to the west by staggered faults on the edges of the SSM and the Sierra de Alvarez (SA) (Figures 3 and 4).

The stratigraphic column in the region includes sedimentary and volcanic rocks ranging in age from Cretaceous to Recent (Figure 3). In the valley, the Cretaceous rocks are mainly thin-layered limestone of Indidura and Cuesta del Cura formations, which have low hydraulic conductivity because these units are from the marine 
basin. Unconformable covering these units are Cretaceous Tertiary volcanic rocks consisting of basalt spills, latites and ignimbrites. These fractured volcanic units reach a thicknesses up to $500 \mathrm{~m}$ and are covered by semi-consolidated granular material with greatly variable thicknesses (from $80 \mathrm{~m}$ to $350 \mathrm{~m}$ and, in some cases, over $500 \mathrm{~m}$ thick). Observed in some areas are interbedded basalts with Quaternary sediments, rhyolitic ignimbrites and tuff sands from the Middle and Upper Oligocene (Labarthe et al., 1982).

Groundwater in the study area is present in Quaternary aquifers with porous alluvial deposits, which consist of laterally discontinuous layers of gravel, sand and clay, and Tertiary volcanic rocks (Figure 3). The aquifer system can be divided according to shallow and deep units. The shallow unit or granular aquifer consists of sand and gravel and extends to a depth of approximately 15 to $200 \mathrm{~m}$ below the ground surface. This unit has good hydraulic conductivity and water production. Above the shallow aquifer, there is a perched aquifer which is poorly distributed in the valley. Its depth is variable with a maximum of $40 \mathrm{~m}$ (Figure 4). The perched aquifer is not hydraulically connected with the deep unit.

The thickness varies in the deep unit; its bottom is between 300 and $800 \mathrm{~m}$ below the ground surface and it is mainly composed of fractured volcanic rocks with good hydraulic conductivity. Because the shallow aquifer unit has been exploited and almost exhausted, pumping wells have been extracting groundwater from the deep unit. Therefore, for the purpose of this study, the deep unit is considered a flow system for a confined aquifer.

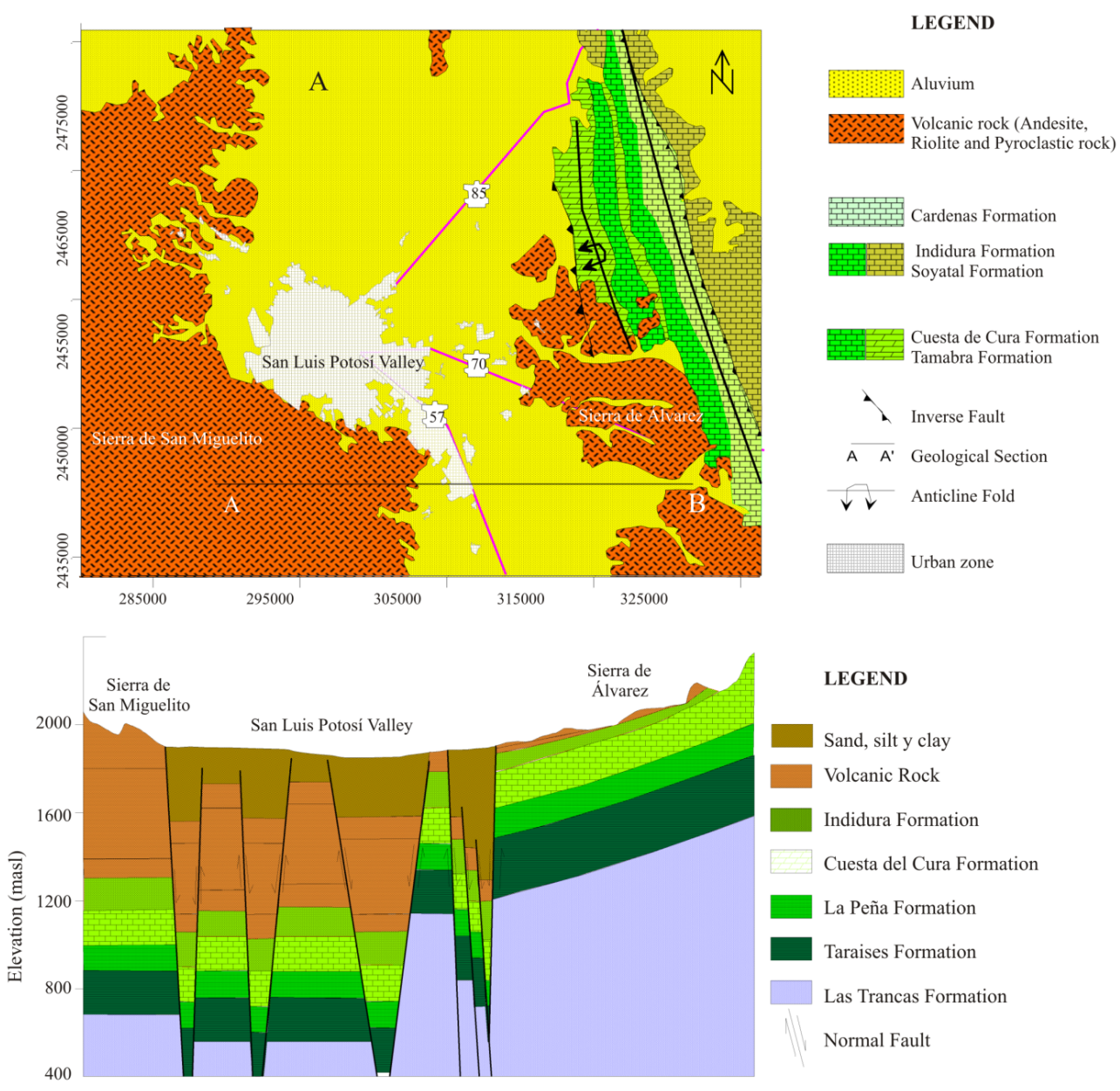

Figure 3. (A) Geology of San Luis Potosí Valley and (B) Hydrogeological section of San Luis Potosí Valley 


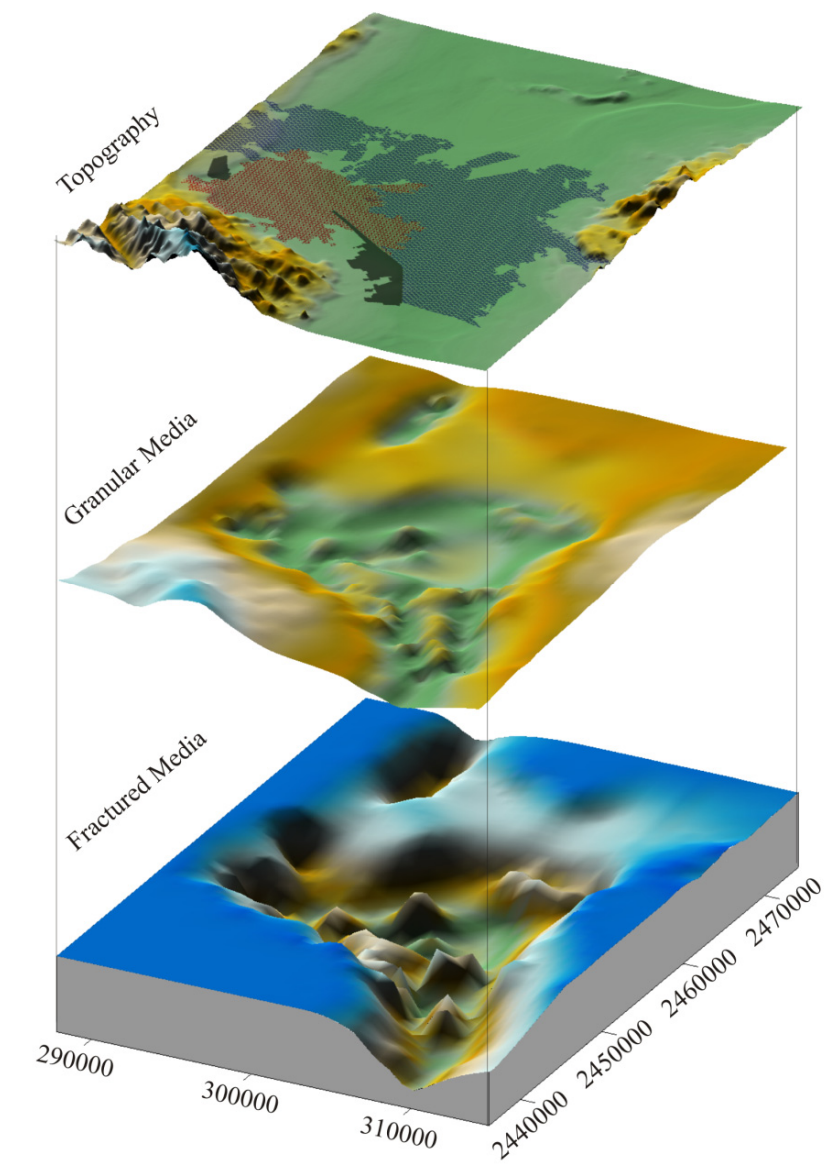

Figure 4. Geometry of the San Luis Potosí Valley aquifer system

\section{Conceptual Model}

Large aquifers are relevant due to their considerable size and as potential water sources. Regional groundwater modeling of this kind of aquifers remains a challenge because the geologic complexity and data scarcity in space and time (Rodriguez et al., 2012). The model includes an area that extends from the airport in the northern region of the city of San Luis Potosí to the town of La Pila in the southern part of the valley (groundwater divide), and from the SSM border in the west to the SA border in the east (Figure 4). The topography was obtained from digital terrain models (INEGI, 2007). The conceptual model (aquifer system) consists of two main units; a shallow aquifer which consists of a granular media (Layer 1). The second unit, the deep aquifer, consists of fractured volcanic rocks (Layer 2). The hydrogeological basis consists of argillaceous limestone, laminated with low hydraulic conductivity (Figure 3).

\subsection{Hydrogeological Evolution and Hydraulic Heads}

The initial hydraulic head corresponds to the year 1986. Water table (SL) elevations for this year range from 1740 to 1757 meters, with a level difference of $17 \mathrm{~m}$. The lowest elevation is located in urban zones in the central SLPV, and the largest are located in the northern, southern and eastern regions of the SLPV. During the year 1995, SL elevations ranged from 1695 to $1805 \mathrm{~m}$, with a level difference of $110 \mathrm{~m}$. For 2007, they ranged from 1673 to $1872 \mathrm{~m}$, with a level difference of $199 \mathrm{~m}$. In Figure 5, a decrease in the water table of 0.6 to 1.6 meters annually during a period from 1977 to 2007 is shown.

The apparent increase of maximum values in the water table is associated with areas where two factors are involved: there are areas that contribute by agricultural irrigation returns and in other cases the presence of faults affects the increase of values in the water table.

The Ministry of Water Resources (SARH, 1977) defined the direction of groundwater flow as running from the periphery of the valley to the urban area. This can be considered the first stage in the generation of the drawdown cone. 
By 1986, Martínez determined that the water tables varied $140 \mathrm{~m}$ in the center of the urban area of the city of SLP and $130-120 \mathrm{~m}$ in its periphery, while in the north and northeast (Candido Navarro and Peñasco), they varied $75 \mathrm{~m}$ and $70 \mathrm{~m}$, respectively. This confirms that the flows are radial to the periphery of the valley and towards the large drawdown cone in the SLP urban area, with a decrease of $2.6 \mathrm{~m} / \mathrm{year}$.

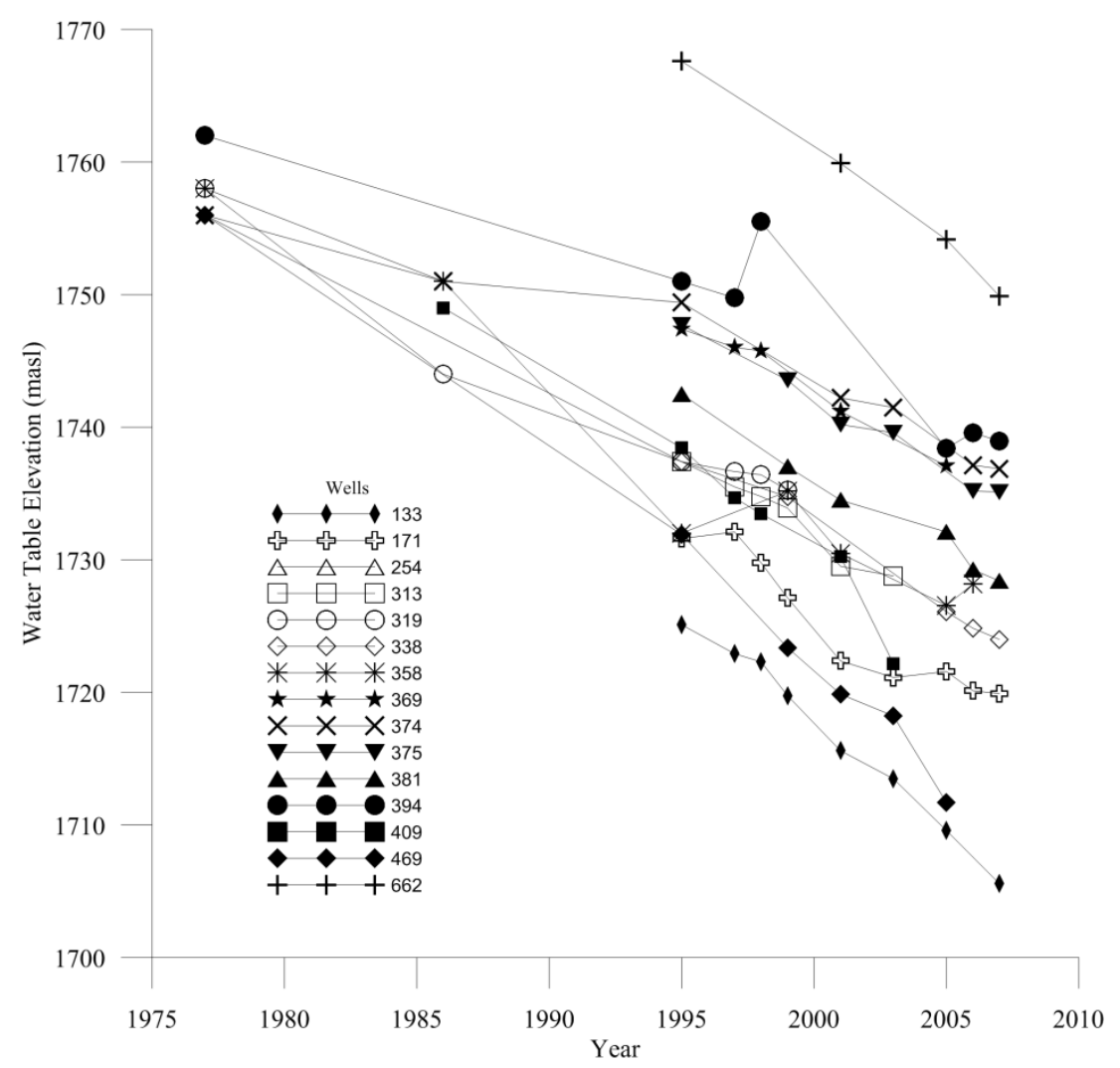

Figure 5. Temporal evolution of the water table in several observation points in SLPV from 1977 to 2007

Based on the 2003 piezometric network, the drawdown cone is observed to be predominant in the city of SLP. The hydraulic gradients converge towards the regional drawdown cone and the depth of the cone increased $60 \mathrm{~m}$ from 1971 to 1995 (CNA, 1996-b). The evolution of the water table for the period 1995-2001, its depth increased as much as $25 \mathrm{~m}$ in the center of the drawdown cone and developed towards the north, while in certain areas there were no water level drawdowns (COTAS, 2005). In 2007, a new direction in the expansion of the drawdown cone was observed, which goes from the center of the SLP urban area toward the southern region of the city.

For calibration, historical data were used from water tables from 21 wells in the monitoring network of the deep aquifer. The depth of the wells varies from 200 to $726 \mathrm{~m}$.

\subsection{Aquifer Properties}

The values used for the initial estimates of hydraulic conductivities, the storage coefficient, transmissivity and specific storage for the domain model were based on those reported in previous studies (Cardona-Benavides, 1990, 2007; Carrillo-Rivera et al., 1992, 2002), as well as values commonly accepted in the literature for materials similar to those in the study area (Figures 3, 4, 6 and Table 1).

Hydraulic conductivities in layer 1 are related to the distribution of materials in the alluvial valley (Figure 6). They have a range of conductivities from 0.1 to $50 \mathrm{~m} / \mathrm{d}$. The lowest values are located in the northeast part of the valley, while the highest are distributed in areas that coincide with the presence of geological faults (Figures 3, 4, and 6).

In layer 2, hydraulic conductivities have a range of conductivities from 2 to $10 \mathrm{~m} / \mathrm{d}$. The highest are distributed in areas that coincide with geological faults too (Figures 3, 4 and 6). 


\section{Numerical Model}

The numerical flow model was constructed using the MODFLOW (McDonald \& Harbaugh, 1988) algorithm based on block-centered finite differences and a three-dimensional graphic interface. The flow model was calibrated in stationary conditions.

\subsection{Equations}

A general solution for the response of multiple aquifer systems to pumping stress requires solving the three-dimensional flow equations (Bredehoeft et al., 1970). The three-dimensional flow of constant-density groundwater through a porous medium can be described by the partial differential equation:

$$
\frac{\partial}{\partial x}\left(k_{x x} \frac{\partial h}{\partial x}\right)+\frac{\partial}{\partial y}\left(k_{y y} \frac{\partial h}{\partial y}\right)+\frac{\partial}{\partial z}\left(k_{z z} \frac{\partial h}{\partial z}\right)+W=S \frac{\partial h}{\partial t}
$$

Where $\mathrm{h}$ is the head hydraulic (L), $\mathrm{t}$ is time (T), Kxx, and KZZ Kyy are values of the hydraulic conductivity along the $\mathrm{x}, \mathrm{y}$ and $\mathrm{z}$ coordinate axes, which are assumed to be parallel to the principal axes of the hydraulic conductivity (LT-1), $\mathrm{W}$ is the volumetric flow rate per unit volume and represents water sources and/or sinks (T-1) and Ss is the specific storage of porous material (L-1).

The MODFLOW computer code developed by the USGS (McDonald \& Harbaugh, 1996) was used to solve the flow model and the pre-and post-processor Visual MODFLOW (VM) Pro version 4.1 (a product owned by Waterloo Hydrogeologic Inc., 2005) was used to plot the input data for analysis and presentation of the output data.

\subsection{Spatial and Temporal Discretization}

The discretization of the finite-difference flow model is shown in Figure 6. The grid contains 30 columns and 34 rows with a constant spacing of $1000 \mathrm{~m}$. Vertically, two layers were defined in the model to simulate the two-dimensional regional flow system. The first layer comprises alluvial deposits and granular medium (shallow aquifer) and the second represents fractured volcanic material (deep aquifer). The elevations of the roof and the bottom of the layers were interpolated from a geoelectric model of the study area. In the present study, we simulated the groundwater flow in SLPV for the time period from 1986 to 2007.

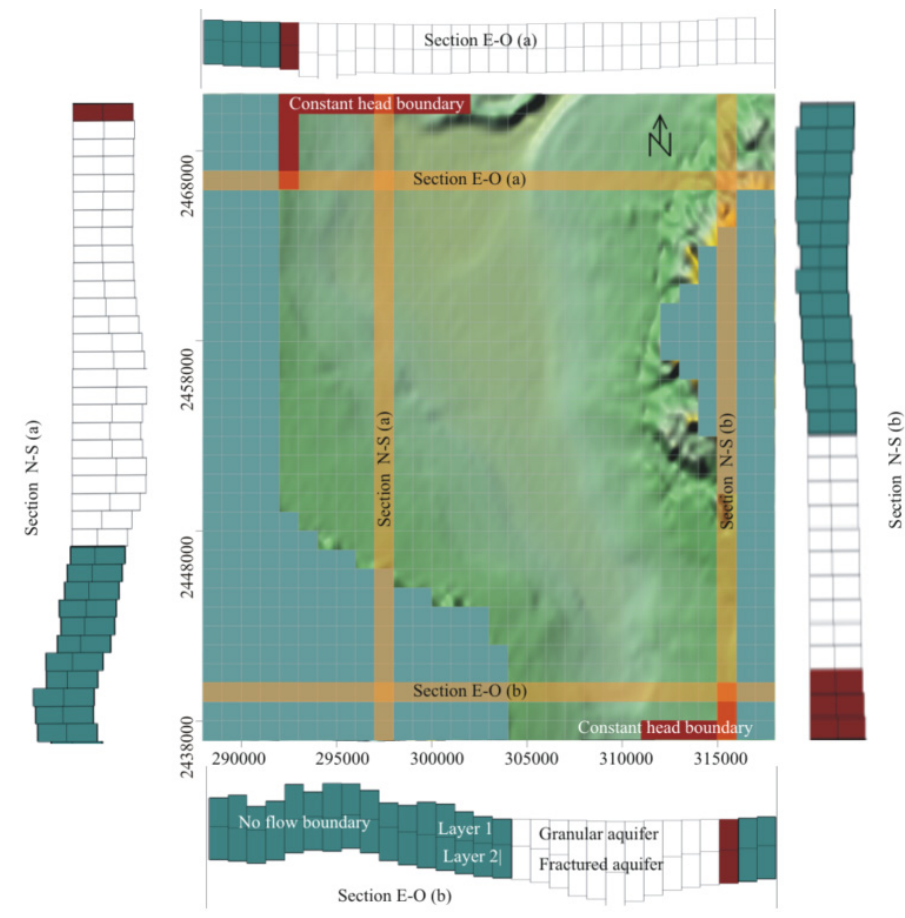

Figure 6. Spatial discretization and boundary conditions of the model 


\subsection{Boundary Conditions}

The physical and hydraulic boundaries in the study area were defined from available geological and hydrological information (Figure 6). On the east and west edges of the interface model is located the interface between the plains and the mountainous terrain of the SSM and SA, respectively. The mountain-front recharge enters the study area laterally, while the east and west boundaries of the model were defined as no-flow boundaries. Dirchlet (constant head) boundary conditions were imposed on the northeast and southwest borders. The values of the constant heads for 1986 in the northeast and southwest borders were 1753 and $1744 \mathrm{~m}$, respectively (Martínez \& Aguirre, 1987).

\subsection{Recharge and Lateral Input}

The main sources of groundwater recharge for the shallow aquifer in the study area are lateral flow from the surrounding mountains and irrigation return flow. The fact that evapotranspiration and precipitation rates are similar limits the deep aquifer recharge.

The rivers that run through the valley are intermittent and therefore were not considered as elements of aquifer recharge. Nevertheless, open channels are located in the agricultural zone of SGS, through which wastewater flows constantly. Although farming generates artificial recharge due to irrigation returns, it goes into the perched aquifer, but only in areas where the aquifer behaves freely, since the rest of the area is urbanized, covered by a thin layer of clay or layer caliche which prevents infiltration into the perched aquifer.

Three distinct recharge areas were determined. The most influential was for the agricultural area $(15 \mathrm{~mm} / \mathrm{year})$, the second the urban area $(10 \mathrm{~mm} /$ year) and the third were for the rest of valley $(7 \mathrm{~mm} /$ year) (Figure 7).

Lateral recharges from the SSM and the SA, which constitute the most important orographic areas in the SLPV, contribute little due to low permeability, making infiltration into the subsoil very difficult. Regional recharge is mainly generated in the northwest portion of the study area.
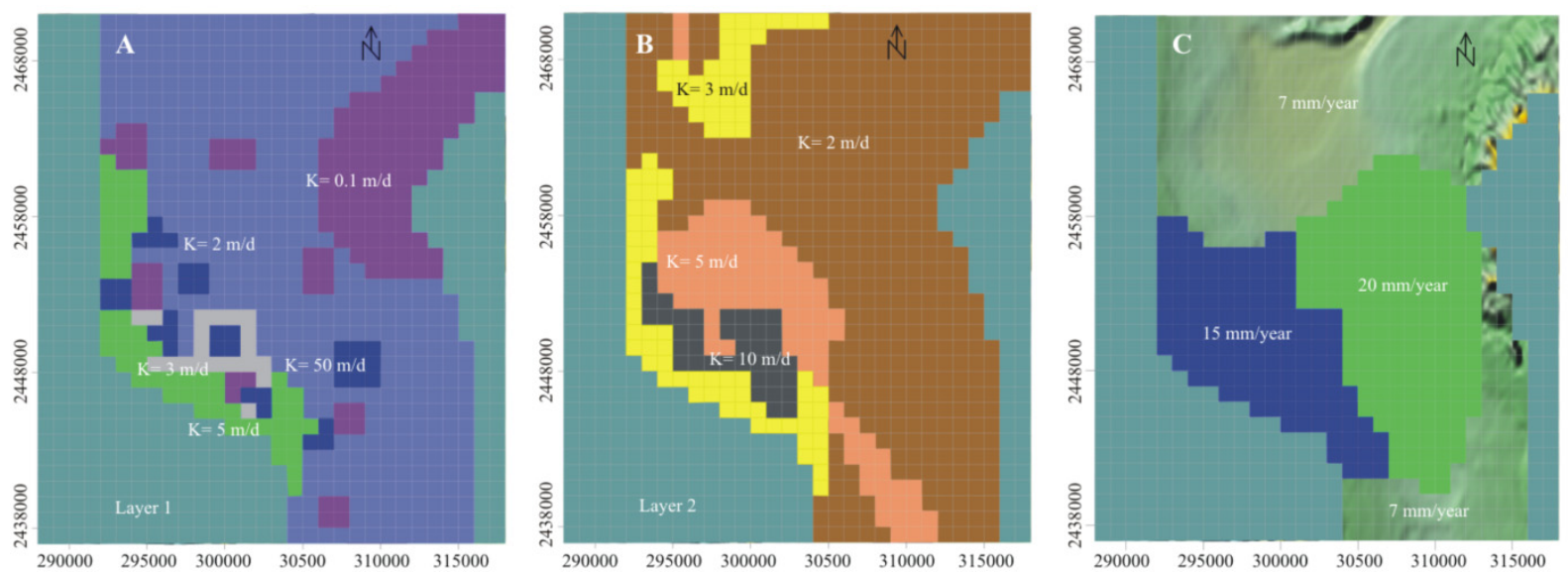

Figure 7. (A and B) Hydraulic conductivity assigned to areas in the study area: Layer 1, granular aquifer; Layer 2, fractured aquifer. (C) Distribution of recharge rates in the model

\subsection{Extraction}

The extraction of groundwater from the deep aquifer produces an average drawdown of $1.3 \mathrm{~m} / \mathrm{year}$. Overall, while the drawdown in the deep aquifer varies between 1 and $50 \mathrm{~m}$, the average for the wells located in volcanic rocks and in granular medium are 20 and $14 \mathrm{~m}$, respectively.

The two most recent statements made by COTAS (2005) were for the years 1995 and 2002.

In the balance of 1995 there was a deficit of $36.66 \mathrm{Mm}^{3} /$ year. For the balance of 2002 , the extracted volume was $120.6 \mathrm{Mm}^{3} /$ year with a recharge of $78.1 \mathrm{Mm}^{3} /$ year, giving a deficit of $42.5 \mathrm{Mm}^{3} /$ year. However, the values of recharge balances are not adequate because in these reports, the inputs and outputs of the system are mixed, i.e., the main extraction is carried out in the confined aquifer and the resulting infiltration due to surface balance affects only the perched aquifer. This analysis justifies the condition of the aquifer mining, widely discussed in Noyola et al. (2009) for SLPV. 
The main discharge in the study area is from pumping for domestic and industrial uses in the city of SLPV and pumping for irrigation in neighboring municipalities. The maximum volume allowed by the authorities to be extracted from the aquifer system is $136 \mathrm{Mm}^{3} /$ year (INTERAPAS, 2004). Individual point wells were used to represent pumping in the city of SLPV.

An analysis of the total volume extracted from the aquifer system by pumping for different uses was conducted by INTERAPAS (2004) for the period 1995-2005. When considering the volume of water demand according to type of use, the majority of the volume extracted was determined to be for human use and consumption, followed by industrial and agricultural uses.

Since 1950, the population has grown at an annual average rate of $3 \%$ with a demand of 200 liters per capita daily. Thus by the year 2005 the urban use represented $78.2 \%$ of the total extraction from the deep aquifer. Industry demanded $11.4 \%$, with an annual growth rate of $0.63 \%$ through 2005 . Meanwhile, the agricultural zone has experienced an annual average decrease of $1.22 \%$ in 2005 , with a demand of $7.4 \%$ of the total extraction from the deep aquifer (Table 1).

\subsection{Calibration}

The numerical model was calibrated to reproduce the measured groundwater levels. This calibration includes two sequential steps. First, the steady-state model was calibrated and developed by adjusting the input parameters, such as hydraulic conductivity and boundary conditions that were able to reproduce behaviors whose characteristics represented the developed aquifer system, until obtaining the optimal condition for the modeling system. The criteria used for the best calibration was mean squared error (MSE). The solution to the steady-state model provides the initial conditions for the transient state model of the flow field from 1986 (Figure 8a). The second step consisted of the verification of the transient model against the measured water levels available for 1995 and 2007 on the model domain (Figures 8b and 8c).
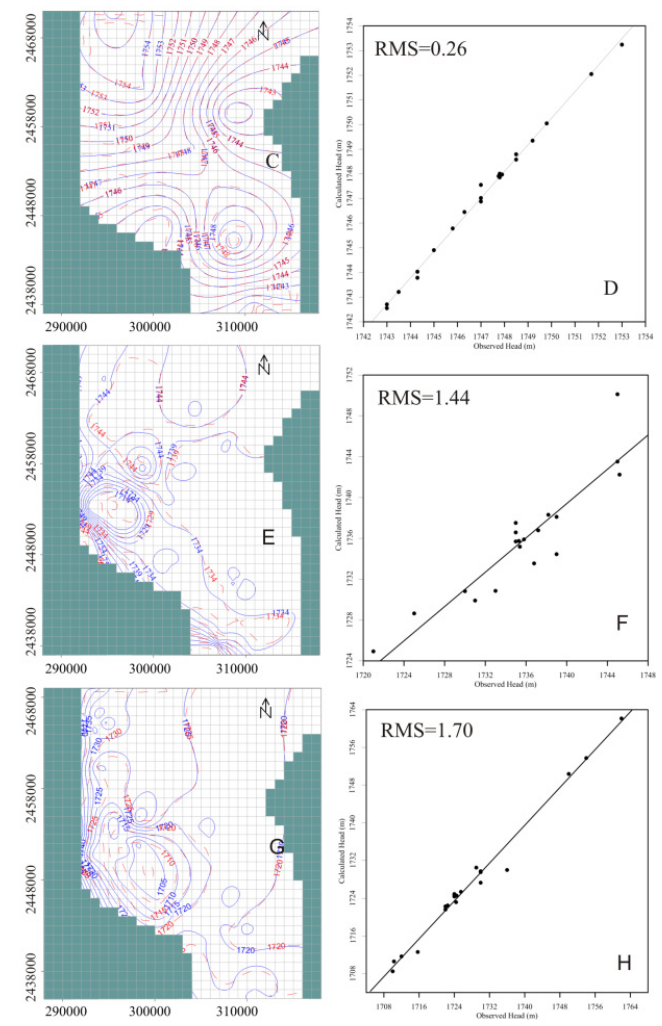

Figure 8. A) Simulation of groundwater flow and calibration in 1986 and correlation between measured and calculated hydraulic head in transient state. B) Verification of the model with data from 1995 and correlation between measured and calculated hydraulic head in transient state. C) Verification of the model with data from 2007 and correlation between measured and calculated hydraulic head in transient state 


\section{Results}

During the calibration tests, several experiments were performed with meshes of $250 \times 250$ and $500 \times 500 \mathrm{~m}$. However the mean square error (MSE) was high and the results were unrealistic. The best results in the calibration process were obtained with a grid spacing of $1000 \times 1000 \mathrm{~m}$. This mesh is suitable for the available information and for the dimensions of this basin. Smaller grid spacing does not lead necessarily to better results. In other studies for similar basin dimensions, the same grid spacing of $1000 \mathrm{~m}$ was also applied (Sanford et al., 2004; Milzow et al., 2009; Yustres et al., 2013). Numerical modeling has allowed simulating an MSE of 0.26 for the transient-state, for the initial conditions of 1986 (Figure 8a).

MSE of 1.44 and 1.70 were obtained for the transient states in 1995 and 2007, respectively (Figures 8b and 8c).

Using the flow model, it was possible to determine a preferential direction from north to south during initial conditions, which were very different from nowadays conditions. The flow directions have been changing as the aquifer has been evolving due to extraction so that the contour of water tables now shows the direction of flow converging towards the urban area, resulting in a drawdown cone (Figure 9).

During the simulation period of 1986, the drawdown cone was observed to be located mainly in the urban areas (central valley) and another in the northeastern portion of the valley, while for the year 2007, the cone in the urban zone began to develop towards the industrial area (southern portion of the valley) as a result of increased extraction due to a change in land use by the agricultural to industry.

Based on the flow model and considering population growth projections and the analysis of land use changes, predictive simulations were performed to define groundwater management scenarios, which found that the amount allowed by CONAGUA would be reached by 2021 (Figure 9).

Considering the recent developments in the urban and peri-urban valley since 1950, predictive simulations were performed in which urban and industrial changes in land use were inversely proportional to the change in agricultural use (Figure 9). It impacted directly the recharge rate in the agricultural zone. Another way to see the exchange of water used by agriculture with that used in the industry is to consider the percentage change between 1996 and 2005.
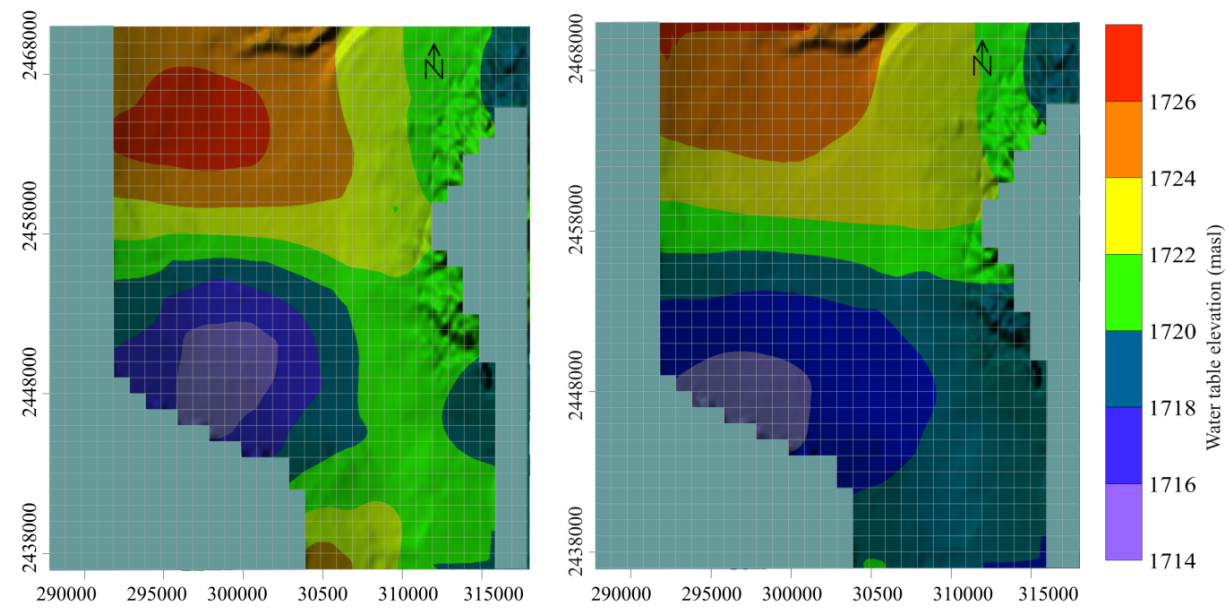

Figure 9. Predictive simulations. A) Considering population growth projections, the analysis of land use changes and volume allowed by the CONAGUA reached in 2021. B) Considering a constant extraction rate of 136 $\mathrm{Mm}^{3} /$ year for 50 years

Figure 10 shows that human consumption impacts more on the total extraction system of SLPV, it has increased steadily since the end of last century. In the period under review, there has been an increase in volume for industrial use. This volume was compensated by a decrease in the extracted volume for agriculture.

These changes are proportional, so that they do not represent a major impact on the trend of the total extraction. But in time, this proportionality does not occur. There will be an impact on the trend of the total extraction (Figure 10).

The main changes were from agricultural to urban land use, and over the last decade, from agricultural to 
industrial land use. In the former case, areas considered to be natural recharge (SSM) for the shallow aquifer have been altered by the urban use of land with the consequence of little or no recharge in the shallow aquifer, causing its depletion and promoting greater extraction of groundwater from the deep aquifer to supply the population.

Similarly, areas that were traditionally of agricultural land use have gradually become urban areas.

Additional projections with the 50-year model calculation show that the drawdown cone develops throughout the valley (Figure 10).

Looking for alternative sources of water supply for the different uses by the population is a priority, given this scenario and the continued increase in the population and industrial activity.

Based on the model results, it is concluded that the distribution of extraction wells, located in the neighborhood of the hydrological boundaries without flow contributions, causes a large drawdown cone and land subsidence in the urban area (López-Álvarez et al., 2013).

The local water sources in the basin are almost depleted. Inside the VSLP, it is necessary to take steps to reduce the extraction in the system and to reuse wastewater in the industry and agriculture. Since extraction for human use impacts predominantly the system, it would be desirable that the water authorities promote campaigns of water culture (water use efficiency and appropriate use). It is also desirable to establish the endowment reduction of the volume of water for each person as well as political and water managements. There should be also considered the water extraction of new areas.

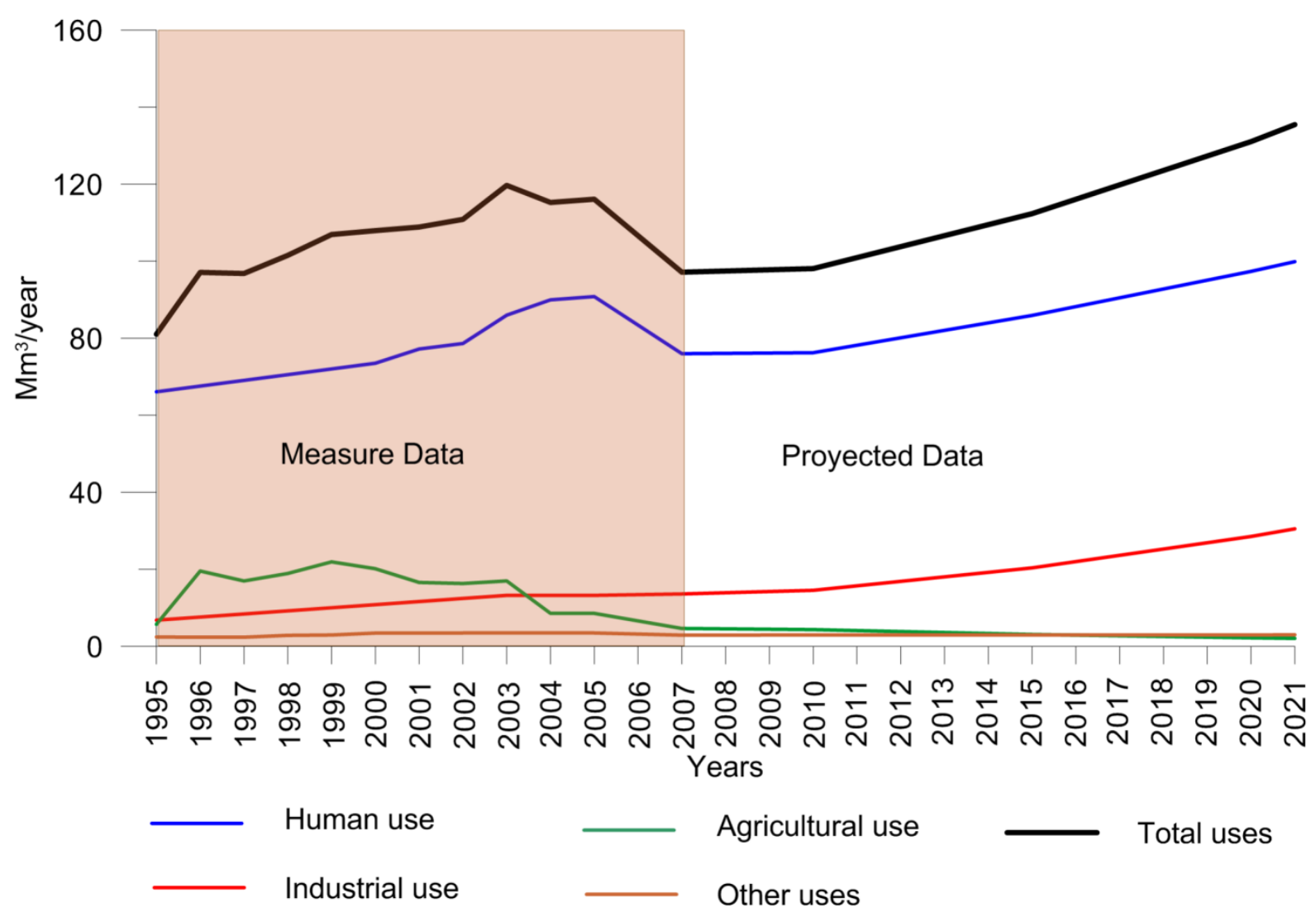

Figure 10. Exchange of water use between 1995 and 2021

\section{Conclusions}

The SLPV has undergone changes in land use over the past 20 years which impacted greatly the aquifer system in the study area.

The main land use changes took place from agricultural to industrial and urban land use.

With the application of the flow model, it was possible to show that the induced recharge has a greater effect 
than the natural recharge, especially on the shallow aquifer, while for the deep aquifer both types of recharge have minimal or no effect.

Numerical simulations show that land use changes have had the greatest impact on the growth of the drawdown cone towards the industrial area.

For the predictive phase, it was identified that the volume established by CONAGUA will be reached in 2021.

The aquifer of VSLP had a drawdown of 199 meters in the period 1997-2007. If this scenario continues, the drawdown will continue in the valley, causing an overall decline in groundwater levels.

The flow model for the SLPV aquifer system shows a clear effect of the risks associated with mining aquifer. Therefore, groundwater management policies appropriate to the precarious conditions of the system need to be implemented.

\section{Acknowledgments}

We wish to thank the project "Social and environmental problems associated with the use and management of water in the basin of San Luis Potosí Valley" which has received funding from the Basic Science SEP-CONA-CYT-151666, in its 2010 edition. We also thank to CONACYT Postdoctoral scholarship in their call 2012 (3).

\section{References}

Anderson, M. P., \& Wang, H. F. (1982). Introducction to groundwater modeling, finite difference and finte elements methods (p. 237). Academic Press, Inc.

Bredehoeft, J. D., \& Pinder, G. F. (1970). Digital Analysis of Areal Flow in Multiaquifer Groundwater Systems, a Quasi Three-Dimensional Model. Water Resources, 6, 883-888.

Bredehoeft, J. D. (2002). The Water Budget Myth Revisited: Why Hydrogeologists Model. Ground Water, 40, 340-345. http://dx.doi.org/10.1111/j.1745-6584.2002.tb02511.x

Cardona-Benavides, A. (1990). Caracterización físico-química y origen de los sólidos disueltos en el agua subterránea en el Valle de San Luis Potosí: su relación con el sistema de flujo: México, Universidad Autónoma de Nuevo León, Tesis de Maestría, p. 97.

Cardona-Benavides, A. (2007). Hidrogeoquímica de sistemas de flujo regional, intermedio y local resultado del marco geológico en la Mesa Central: Reacciones, procesos y contaminación: México, Universidad Nacional Autónoma de México, Instituto de Geofísica, Posgrado en Ciencias de la Tierra, Tesis de Doctoral, $238 \mathrm{p}$.

Carrillo-Rivera, J. J., Clark, I. D., \& Fritz, P. (1992). Investigating recharge of shallow and paleo-groundwaters in the Villa de Reyes basin, SLP, Mexico, with environmental isotopes. Applied Hydrogeology, 1(4), 35-48. http://dx.doi.org/10.1007/s100400050025

Carrillo-Rivera, J. J., Cardona-Benavides, A., \& Moss, D. (1996). Importance of the vertical component of groundwater flow: a hydrochemical approach in the valley of San Luis Potosí, México. Journal of Hydrology, 185, 23-44. http://dx.doi.org/10.1016/S0022-1694(96)03014-4

Carrillo-Rivera J. J., \& Armienta, M. A. (1990). Diferenciación de la contaminación inorgánica en las aguas subterráneas del valle de la ciudad de San Luis Potosí, S.L.P., México. Geofisica Internacional, 28(4), 763-783.

Carrillo-Rivera, J. J., Cardona-Benavides, A., \& Edmunds, W. M. (2002). Use of regime and knowledge of hydogeological conditions to control high-fluride concentration in abstracted groundwater: San Luis Potosí, basin, Mexico. Journal of Hydrogeology, 261, 24-47. http://dx.doi.org/10.1016/S0022-1694(01)00566-2

Chávez-Rodríguez, A., Pinales-Munguía, A., Ducoing-Castillo, R., \& Cruz-José, J. L. (2006). Modelación aplicada a sistemas acuíferos: enfoques y desarrollos en México. Comisión Estatal del Agua de Guanajuato, p. 563.

Comité Técnico del Agua Subterránea (COTAS) y Comisión Nacional del Agua (CONAGUA). (2005). Estudio técnico respecto a las condiciones geohidrológicas y sociales del acuífero 2411 "San Luis Potosí" en el Estado de San Luis Potosí: San Luis Potosí, Comité Técnico de Agua Subterránea del Acuífero del Valle de San Luis Potosí, reporte, p. 74.

Comisión Nacional del Agua (CNA). (1996a). Estudio Hidrogeológico de la Contaminación del Agua Subterránea en la Zona Industrial de San Luis Potosí, S. L. P. 4 Volúmenes. 
Comisión Nacional del Agua (CNA). (1996b). Actualización Geohidrológica del Valle de San Luis Potosí. Informe inédito, 6 pp. Anexo tablas y planos.

Cruickshank, C., Shidawara, M., \& y Rosengaus, M. (1982) Modelo tridimensional de contaminantes de acuíferos en el Valle de México. Instituto de Ingeniería, UNAM. Elaborado para el Departamento del Distrito Federal.

Difurt-Candelaria, A., Martínez-Ruiz, V. J., \& y Martínez, S. (1995) Calibración del Modelo Matemático del Acuífero Profundo del Valle de San Luis Potosí. Informe Técnico, Facultad de Ingeniería, UASLP.

Herrera, I., Yates, R., \& y Hennart, J. P. (1982) Estudio del hundimiento y balance de los acuíferos subterráneos de la Ciudad de México. Instituto de Investigación de matemáticas aplicadas y sistemas, UNAM.

Herrera, I., Martínez, R., \& y Hernández, G., (1989) Contribución para la administración científica del agua subterránea en la cuenca de México. Instituto de Geofísica, UNAM, Geofísica Internacional (28-2), pp. 283-295.

Instituto Nacional de Geografía, Estadística e Informática, INEGI. (1981). Tabulados básicos, X Censo General de Población y Vivienda, 1980, (en cd): México Instituto Nacional de Geografía, Estadística e Informática.

Instituto Nacional de Geografía, Estadística e Informática, INEGI. (1991). Tabulado básicos, XI Censo General de Población y Vivienda, 1990, (en cd): México Instituto Nacional de Geografía, Estadística e Informática.

Instituto Nacional de Geografía, Estadística e Informática, INEGI. (2001). Tabulado básicos, XII Censo General de Población y Vivienda, 2000, (en cd): México Instituto Nacional de Geografía, Estadística e Informática.

Instituto Nacional de Geografía, Estadística e Informática, INEGI. (2007). Carta Topográfica F14-4, escala 1:250 000: San Luis Potosí, San Luis Potosí, México. Impresa y digital.

Instituto Nacional de Geografía, Estadística e Informática, INEGI. (2010). II Conteo de Población y Vivienda 2010: México, Instituto Nacional de Geografía, Estadística e Informática.

Kepner W. G., Ramsey M. M, Brown, M. S., Jarchow, M. E, Dickinson, K. J., \& Mark, A. F. (2012). Hydrologic futures: using scenario analysis to evaluate impacts of forecasted land use change on hydrologic services. Ecosphere, 3, art69. http://dx.doi.org/10.1890/ES11-00367.1

Kohn-Ledesma, I. (2009). Modelo de flujo del acuífero de San Luis Potosí, SLP. Universidad Autónoma de México, Instituto de Geofísica, Posgrado en Ciencias de la Tierra, tesis de maestría, p. 118.

Labarthe-Hernández, G., Tristán-González, M., \& Aranda-Gómez, J. J. (1982) Revisión estratigráfica del Cenozoico de la parte central del estado de San Luis Potosí: San Luis Potosí, México, Universidad Autónoma de San Luis Potosí, Instituto de Geología, Folleto Técnico 85, p. 208.

Lopez-Alvarez, B., Ramos-Leal, J. A., Moran-Ramirez, J., Cardona-Benavides, A., \& Hernández-Garcia, G. (2013). Origen de la calidad del agua del acuífero colgado y su relación con los cambios de uso de suelo en el Valle de San Luis Potosí. Boletín de la Sociedad Geológica Mexicana, 65(1), 9-26.

Mahlknecht, J., Steinich, B., \& Navarro de León, I. (2004). Groundwater chemistry and mass transfers in the Independence aquifer, central Mexico, by using multivariate statistics and mass-balance models. Environmental Geology, 45(6), 781-795. http://dx.doi.org/10.1007/s00254-003-0938-3

Martínez-Ruiz, V. J., \& y Aguirre, M. A. (1984). Comportamiento del Nivel Estático de Acuífero Profundo de la Cuenca de San Luis Potosí, Hasta Junio de 1984. Universidad Autónoma de San Luis Potosí, Instituto de Geología y Metalurgia. Folleto Técnico No. 96.

Martínez-Ruiz, V. J., \& y Aguirre, M. A. (1987). Geohidrología del área de San Bartolo de Berrios, Municipio de San Felipe Guanajuato. Cuenca de Villa de Reyes, S. L. P. Universidad Autónoma de San Luis Potosí, Instituto de Geología y Metalurgia, Folleto Técnico No. 108.

Martínez-Ruiz, V. J. (1986). Condiciones Geohidrológicas Actuales del Valle de San Luis Potosí, Hasta Junio de 1984. Universidad Autónoma de San Luis Potosí, Instituto de Geología y Metalurgia. Folleto Técnico No. 105.

McDonald, M. G., \& Harbaugh, A. W. (1988). A modular three-dimensional finite difference ground-water flow model: U.S. Geological Survey Techniques of Water-Resources Investigations, book 6, chap. A1, p. 586.

Medina, F. (1974). Una Solución al Problema del Agua en San Luis Potosí, S.L.P. Folleto Técnico No. 41, Instituto de Geología y Metalurgia, UASLP.

Milzow, C., Kgotlhang, L. Bauer-Gottwein, P., Meier, F., \& Kinzelbach, W. (2009). Regional review: the 
hydrology of the Okavango Delta, Botswana-processes, data and modeling. Hydrogeology Journal, 17, 1297-1328. http://dx.doi.org/10.1007/s10040-009-0436-0

Noyola-Medrano, M. C., Ramos-Leal, J. A., Domínguez-Mariani, E., Pineda-Martínez L. F., López-Loera, H., \& y Carbajal N. (2009). Factores que dan origen al minado de acuíferos en ambientes áridos: caso Valle de San Luis Potosí. Revista Mexicana de Ciencias Geológicas, 24(2), 395-410.

Organismo Intermunicipal metropolitano de agua potable, alcantarillado, saneamiento y servicios conexos de los municipios de Cerro de San Pedro, San Luis Potosí y Soledad de Graciano Sánchez, INTERAPAS. (2004). Reporte técnico, no publicado, p. 152.

Peña, F. (2006). Abasto de agua a la ciudad de San Luis Potosí, en Barkin, D. (Ed.), La Gestión del Agua Urbana en México: México, Universidad de Guadalajara, 249-264.

Ramos-Leal, J. A., Martínez-Ruiz, V. J., \& Castro-Rodríguez, A. (2005). Vulnerabilidad Acuífera e Índices de Calidad del Agua Subterránea de los Valles de San Luis Potosí-Villa de Reyes. Informe Interno (1er. Informe), Instituto Potosino de Investigación Científica y Tecnológica, IPICYT, p. 35.

Rodríguez, L., Vives, L., \& Gomez, A. (2012). Conceptual and numerical modeling of the Guaraní Aquifer System. Hydrology and Earth System Sciences, 9, 9885-9930. http://dx.doi.org/10.5194/hessd-9-9885-2012

Sanford, W. E., Plummer, W. E., McAda, L. N., Bexfield, D. P., \& Anderholm, S. K. (2004). Hydrochemical tracers in the middle Rio Grande Basin, USA: 2. Calibration of a groundwater-flow model. Hydrogeology Journal, 12, 389-407. http://dx.doi.org/10.1007/s10040-004-0326-4

Secretaría de Agricultura y Recursos Hidráulicos (SARH). Comisión Nacional del Agua (CNA) y Universidad Autónoma de México (UNAM). (1992). Modelación Matemática del Acuífero de San Luis Potosí, para Definir Políticas de Explotación, para Abastecimiento de Agua a la Ciudad de San Luis Potosí. p. 74.

Secretaría de Agricultura y Recursos Hidráulicos, SARH. (1977). Estudio geohidrológico de evaluación y censo de los Estados de San Luis Potosí y Zacatecas, 1a. parte, Zona San Luis Potosí, Contrato EIGZA-77-16G.

Secretaria de Medio Ambiente y Recursos Naturales, SEMARNAT. (2008). Boletín del Archivo Histórico del Agua. Año 13, No. 40, Septiembre- diciembre 2008, p. 89.

Sheridan-Prieto, C. (2001). Indios madrineros Colonizadores tlaxcaltecas en el noroeste novohispano: Estudios de Historia Novohispana, 24, p. 24.

Turner, M. G., Wear, D. N., \& Flamm, R. O. (1996). Land Ownership and Land-Cover Change in the Southern Appalachian Highlands and the Olympic Peninsula. Ecological Applications, 6, 1150-1172. http://dx.doi.org/10.2307/2269599

United Nations Educational, Scientific and Cultural Organization, UNESCO. (2004). Groundwater contamination Inventory: a methodological guide. Project 3.1 (IHP-V), p. 162.

Yustres, A., Navarro V., Asensio, L., Candel, M., \& García, B. (2013). Groundwater resources in the Upper Guadiana Basin (Spain): a regional modelling analysis. Hydrogeology Journal. http://dx.doi.org/10.1007/s10040-013-0987-y

\section{Copyrights}

Copyright for this article is retained by the author(s), with first publication rights granted to the journal.

This is an open-access article distributed under the terms and conditions of the Creative Commons Attribution license (http://creativecommons.org/licenses/by/3.0/). 